\title{
Archaeological evidence for a destructive earthquake in Patras, Greece
}

\section{Introduction}

The understanding of the seismic hazard in certain parts of the world, for instance in Italy, Greece, Turkey and the Middle East is to a major degree based on historical data. Historical seismicity catalogues are based on such data (for instance, Papazachos and Papazachou 1997; Guidoboni et al. 1994). Still, such catalogues are silent for certain areas and periods, indicating either absence of seismicity or incompleteness of historical data. The town of Patras is a notable example. The wider area is seismically active and adjacent to the west edge of the Aegean Arc, marked by intense ground deformation. It was last hit in 2003 by a magnitude 5.1 earthquake (Plicka et al. 1998) and in 2008 by an earthquake of magnitude 6.4 (Ganas et al. 2009; Gallovič et al. 2009; Margaris et al. 2010; Feng et al. 2010). The particularity of the latter earthquake, the first strike slip event documented on land in Greece, is that it corresponds to a blind young or nascent fault, which is likely to have been associated with at least four events with magnitude $>5.0$ in the last 20 years, and with a sense of NW progression; Feng et al. 2010, Stiros et al. 2013). If this is true, then a new earthquake with epicentre close to Patras may be expected in the near future. This situation is reminiscent of the seismic risk of Istanbul, in relation to the westward reactivation of the North Anatolian Fault (Stein et al. 1997; Atakan et al. 2002).

This possibility makes necessary the study of the seismic history of the Patras area. A history that appears at least questionable. Apart from a cluster of earthquakes in the $18-19^{\text {th }}$ century, and a vague report for an earthquake in AD551 (see below) no other earthquakes are known to have hit Patras. And this is quite surprising, for this town was a major harbour and administrative centre in the Roman period, a theatre of military activities, as well as a religious and cultural centre for various periods. Interestingly, the Scottish flag and the spread of Christianity in Scotland are associated with transportation of the relics of Saint Andrews from Patras, where he martyrized (crucified in a X-shaped cross), to St Andrews in Scotland in the $6^{\text {th }} \mathrm{c} \mathrm{AD.}$ In order to contribute in the understanding of the seismic history of Patras, in this article we focus on evidence of earthquakes derived from archaeological excavations and try to correlate this evidence with the available historical data.

Evidence comes from "rescue" (rapid, emergency) excavations. In such cases, the only aim and possibility for the excavator is simply to identify possible ancient remains, collect important artefacts to be transported in the warehouses of a museum, and leave the space ready for building activities. In rare cases, a report for the excavation is published, hardly exceeding few lines in length. Only in the case of very important remains (temples, gates in walls etc.) the site is confiscated by the government and then partially excavated and preserved in a proper manner.

Because most excavations in Patras were of rescue type, during the building boom period of the city (1970-2000) very little is known about the findings, 
and for this reason detailed studies of the history and archaeology of Patras provide no information of earthquakes (e.g. Rizakis 1995).

While this study permits to present for the first time evidence of seismic destruction in Patras, it does not permit to associate it with a specific fault. It allows only for an estimate of the earthquake intensity and restriction of the causative fault at a distance of $15-20 \mathrm{~km}$ from the city.

\section{Historical evidence of earthquakes in Patras area}

Historical seismicity catalogues (e.g. Guidoboni et al. 1994; Papazachos and Papazachou 1997) include a few entries for earthquakes in the wider Patras region in $A D 551$ (a rather vague report, probably mixing several events), in $1714,1785,1804$ and 1806. Very few details are known about these earthquakes, for which Papazachos and Papazachou (1997) estimated magnitudes between 6.2 and 6.5 of the Richter scale and intensities up to IX. The only additional information concerning these events comes from a passing report of Leake, a famous traveller who, during his visit in the area circa 1805 , noticed that the town was frequently shaken by earthquakes, and for this reason he reported that the house of the British consulat was made of timber, earthquake resistant (see Stiros 1995). Leake's report is likely to indicate effects of the 1804 (and 1806?), of the 1785 or even of the 1714 earthquakes.

\section{Excavation data}

Two rescue excavations provide clear evidence of earthquake destruction

\subsection{Excavation 1: Road with collapsed columns}

\subsubsection{Excavation data}

According to Stavropoulou-Gatsi (1985), a rescue archaeological excavation in 1979 in the centre of the modern city of Patras (Kalamodgarti 10-Kanakari st.), at the depth of approximately $3.5 \mathrm{~m}$ below modern ground level, brought to light remains of a paved road of the Roman period. The excavation was confined to a specific lot covering an area approximately $11 \mathrm{~m}$ by $10 \mathrm{~m}$ wide and was made in the framework of excavations for the foundations of a new building. The output of the excavation was summarized in a short report containing a detailed drawing, a photo (Fig. 2) and a short text.

According to the excavation report, the main finding was part of a well-built paved road, on which four columns from the façade of a major building were found toppled down as a rigid body, nearly parallel to each other. This colonnade was built in the position of the northern sidewalk of the road, while another, later wall was built on the sidewalk of the south side of the road, destroying the uppermost part of the fallen columns (Fig. 2). The original road was approximately $4 \mathrm{~m}$ wide, and signs of erosion from wheels of coaches were reported to have been preserved on the road pavement. All remains were assigned to the Roman period, but no artefacts permitting a finer dating were found.

After the excavation a new building was erected but the remains of the road are preserved beneath a protective layer of sand and gravel, while the column 
fragments and other significant remains have been transported to the warehouse of the local museum. No other excavations in the vicinity of this site were made.

\subsubsection{Building and destruction phases}

The available excavation data permit to identify several phases of construction-destruction in this excavation: After a certain period of use of the road (phase A), testified by the signs of erosion by wheels on the road pavement, a public building with a colonnade on its façade was built along the northern sidewalk of the road (phase B). Phase B ended with the collapse of the building and toppling of the columns on the road pavement. A layer of debris from the destruction covered the area, and at a later period a new building phase (phase $\mathrm{C}$ ) started, as derived from the wall founded along the south sidewalk.

\subsubsection{Causes and dating of building phases}

The excavation report, despite its short length, is clear and complete and permits certain reliable conclusions for the sequence of building phases and a rough dating of destruction reported. The change from phase $A$ to $B$ indicates a major discontinuity in the history of the town, the causes of which cannot be inferred; the possibility of a major destruction and partial change of the urban plan of the area cannot be excluded (cf. Rheidt 1996).

Concerning the destruction marking the passage from phase $\mathrm{B}$ to $\mathrm{C}$, on the contrary, certain lines of evidence provide clear evidence of earthquake destruction:

First, the oriented collapse of the four monolithic columns provides evidence of a pattern of seismic destruction first recognized by Lanciani (1918) and subsequently classified as a criterion of seismic destruction (Stiros 1996; Jones and Stiros 2000; Hancock and Altunel 1997; Galadini et al. 2006; Hinzen 2009; Bottari et al., 2009). This pattern excludes the possibility of a deliberate destruction, usually during a civil war, demolition of ancient temples by Christian zealots, etc.

Second, the four monolithic columns, a precious building material in antiquity, were abandoned and buried under a large mass of debris, representing the background for a new building phase $\mathrm{C}$.

This situation testifies to a major destruction causing disorganization of the city, somewhat analogous to what has been observed in a larger scale in other regions (Rheidt 1996; Stiros and Papageorgiou 2001). The evidence permits to safely assign the destruction marking the end of phase $\mathrm{B}$ according to the criteria of Stiros (1996) and an intensity of the order of IX is likely. The excavation data do not provide detailed dating of the buildings phases, but the style of the colonnade is likely to indicate the first centuries of the Roman occupation. The defeat of Greeks by Romans in 146BC or even the installation of a Roman colony in Patras after the Battle of Actium in 31BC can be considered as a lower bound for phase $A$, while phase $C$ can be dated to the byzantine period (approximately before AD 1000).

\subsection{Excavation 2: Collapsed Oracle Workshop}

A few hundred meters away from the first excavation, another excavation, near the ancient Patras harbour and St Andrews Cathedral (67-69 
Bouboulinas Street) brought to light the remains of a workshop for oil lamps sold at a nearby oil-lamp oracle, popular especially among sailors in Roman times. A major destruction of this workshop was observed and was assigned to a destructive earthquake, because of the style of collapsed buildings and abandonment of the workshop. This earthquake was dated shortly after AD 300 on the basis of the artefacts found, and was assumed responsible for a subsequent demise of Patras (Petropoulos 1999). The available data, however, do not satisfy the strict criteria for identification of earthquakes from archaeological data of Stiros (1996), because the available data focus on the typology of important archaeological findings and the possible seismological evidence is not available, no signs of destruction beyond the capacity of human beings are available, and in addition, the destruction is dated to a turbulent period marked by the war between paganism and Christianity, which ended in AD 310 with the Edictum Mediolani (Decree of Constantin the Great for recognition of Christianity).

\section{Seismological and archaeological implications}

The destruction of the building with the colonnade can be assigned with much confidence to an earthquake with intensity at least IX. The epicentre of this earthquake should have been close to the centre of Patras, perhaps not more than 10-15 km away, because on the grounds of earthquake engineering a local earthquake is required to explain destruction of one or two-storey buildings (Stiros 2001; 2010). There is independent evidence for that in the wider study area: Ambraseys and Jackson (1990) showed that the attenuation of seismic waves in central Greece is rather quick: Among at least ten well documented shocks with magnitude between 6.5 and 7.2 that occurred in Greece between 1890 and 1990, none produced intensities larger than VI at a distance of a few tens of kilometres from its epicentre. The inferred scale of destruction in Patras requires either an earthquake of minimum magnitude 7.0 at a distance of up to $20-30 \mathrm{~km}$ from Patras, or a smaller, magnitude 6.0 to 6.5 earthquake with an epicentre much closer to the town.

The possibility of another, older event which led to partial abandonment of a central street also exists, but the available evidence does not permit any further hypotheses, including the association of these events with the AD 61 or other earthquakes of the $1^{\text {st }}$ century mentioned above, which, however, may have their epicentres away from Patras.

The destruction of the oil lamp workshop at circa AD 300 clearly indicates a major catastrophe, which, according to Petropoulos (1999), was seismic in origin and may have led to the demise of Patras. This last destruction cannot be safely assigned to an earthquake, and despite the proximity of the two sites, and even if it reflects an earthquake, it is not safe to be correlated with the first excavation because the dating of both events is not precise and Patras may have been affected by several earthquakes in the Roman period (in fact, even the transition from phase A to B may indicate an earthquake, see above).

The earthquake or possibly the earthquakes deduced from the archaeological excavations may have been associated with the destruction of the theatre (Odeon) of Patras (Fig.3; an aerial view of this theatre is available in http://www.stepka.gr/mnemeia/patra/romaiko-odeio/), roughly dated to the end 
of the third century AD. Due to lack of other evidence, the destruction of this theatre, built after AD 125, is assigned to a barbaric invasion (see Rizakis 1995, entry 259). Still, the scale of structural damage in this structure (Fig. 3) calls for forces far beyond those of vandalizing raids, and may reflect seismic effects, as has been documented in two other theatres, the theatre of Aigeira (about $60 \mathrm{~km}$ east of Patras in the $3^{\text {rd }} \mathrm{c}$. AD affected by a major earthquake associated with coastal uplift Stiros, 1998) and the theatre of Larissa (in northcentral Greece, damaged by an earthquake; Caputo et al. 2011).

There are some additional remarks to make.

First, archaeological data permit to identify earthquakes and estimate their local intensity and date of occurrence, but they do not usually permit to associate them with specific tectonic features. In the best of the cases, these earthquakes are related to nearby faults, most likely some of those shown in Fig. 1a. To provide an idea of the moderate seismicity, which for the region of Patras is of magnitude above 4 of the Richter scale, we provide the location of all earthquakes with $M>4$ that occurred in the period $1994-2014$ within a radius of $40 \mathrm{~km}$ from the city of Patras (Fig. $1 \mathrm{~b}$ ).

Second, evidence presented indicates that the absence of reports of earthquakes in the ancient texts is not indicative of absence of earthquakes, and

Third, barbaric invasions (or other deliberate destructions) may offer a good explanation for observed damages in ancient buildings or sites only if damages are below a certain level. For instance, the destruction of whole, well-built towns in Libya cannot be assigned to camel-riding tribes, which at best could set fires or make damages, but are associated with the AD 365 earthquake sequence (Stiros 2001). Similarly, earthquakes may represent a reliable explanation for destructions only if the additional necessary evidence for a strong earthquake with an epicentre at a distance less than $20 \mathrm{~km}$ away, either historical or with destructions having a characteristic pattern, exists (Stiros 1996).

\section{Conclusions}

After a period of relative seismic quiescence of about 200 years, the city of Patras in SW Greece is possibly exposed to the threat of earthquakes, but its seismic risk is poorly constrained. This is to some degree due to the poor knowledge of the seismic record of the area.

In this paper we documented the first case of a destructive earthquake in Patras. The evidence comes from a small ancient site in the centre of Patras, but it provides clear evidence of a town-wide devastation which can be explained by an earthquake which produced minimum intensities IX. Association of this earthquake with a specific fault is, however, for the present not possible.

\section{Acknowledgements}

This paper has benefited from the comments of an anonymous reviewer and the Editor-in-Chief. 


\section{References}

Ambraseys N, Jackson, J (1990) Seismicity and associated strain of central Greece between 1890 and 1988. Geophys J Int 101: 663-708

Atakan K, Ojeda A, Meghraoui M et al (2002) Seismic hazard in Istanbul following the 17 August 1999 İzmit and 12 November 1999 Düzce earthquakes. Bull Seismol Soc Am 92: 466-482

Bottari C., Stiros S.C., Teramo A. (2009) Archaeological evidence for destructive earthquake in Sicily between 400BC and AD600, Geoarchaeology, 24(2), 147-175

Caputo R, Hinzen KG, Liberatore D et al. (2011) Quantitative archaeoseismological investigation of the Great Theatre of Larissa, Greece. Bull Earthquake Eng 9(2): 347- 366

Feng L, Newman A, Farmer GT et al. (2010) Energetic rupture, coseismic and postseismic response of the $2008 \mathrm{Mw} 6.4$ Achaia-Elia earthquake in Northwestern Peloponnese, Greece: An indicator of an immature transform fault zone. Geophys J Int 183:103-110

Galadini F, Hinzen KG, Stiros S (2006) Archaeoseismology: methodological issues and procedure. J Seismol 10:395-414

Gallovič F, Zahradník J, Kř́žová D et al. (2009) From earthquake centroid to spatial-temporal rupture evolution: Mw 6.3 Movri Mountain earthquake, June 8, 2008, Greece. Geophys Res Lett 36(21): art.no.L21310

Ganas A, Serpelloni E, Drakatos G et al. (2009) The MW 6.4 Achaia-Elia (Western Greece) earthquake of 8 June 2008: seismological, field, GPS observations, and stress modelling. J Earthquake Eng 13(1):101-124.

Guidoboni E, Comastri A, Traina G (1994) Catalogue of earthquakes in the Mediterranean region up to the $10^{\text {th }}$ century. Istituto Nazionale di Geofisica, Rome

Hancock PL, Altunel E (1997) Faulted archaeological relics at Hierapolis (Pamukkale), Turkey. J Geodyn 24:1-4

Hinzen K (2009) Simulation of Toppling Columns in Archaeoseismology. Bull Seismol Soc Am 99(5):2855- 2875

Jones R, Stiros S (2000) The advent of archeaoseismology in the Mediterranean. In: McGuire et al. (eds) The Archaeology of Geological catastrophes, Special Publication 171. Geological Society of London, London, pp.25-31

Lanciani R (1918) Segni di terremoti negli edifizi di Roma antica. Bull Comm Archaeol Communale, Roma, pp.1-30Margaris B, Athanasopoulos G, Mylonakis G et al. (2010) The 8 June 2008 MW 6.5 Achaia-Elia, Greece earthquake: source characteristics, ground motions, and ground failure. Earthquake Spectra 26:399-424

Papazachos B, Papazachou C (1997) The earthquakes of Greece. Editions Ziti, Thessaloniki

Petropoulos M (1999) The Roman workshop of oil lamps in Patras and the Oracle of oil lamps (in Greek). TAPA, Publication no 70, Patras

Plicka V, Sokos E, Tselentis GA, Zahradník J (1998) The Patras earthquake (14 July 1993): Relative roles of source, path and site effects. J Seismol 2(4):337-349 


\section{Figure captions}

Fig. 1 (a) Location and tectonic map of the wider Patras area, modified after Pérouse et al (unpublished). The 2008 strike-slip fault which was reactivated four times in the last 20 years and with a principal sense of migration of fault activity towards NE (i.e. towards Patras; Feng et al. 2010; Stiros et al. 2013) is marked as the Achaia-Elia Fault. The area within the black dashed box is the area presented in Fig. 1b. (b) Recorded moderate seismicity $(M>4)$ for the region of Patras within the period $1994-2014$. Red circles represent earthquakes with $4 \leq M<5$, blue for $5 \leq M<6$ and yellow for $M \geq 6$ (fig. $1 \mathrm{~b}$ was created using Trimble Business Centre with data obtained from the

Rheidt K (1996) The 1296 earthquake and its consequences for Pergamon and Chliara. In: Stiros S and Jones RE (eds) Archaeoseismology, British Rizakis A (1995) Achaie I: Sources textuelles et histoire regionale Meletimata 20. Centre de Recherches de l'antiquite grecque et romaine (Athenes), Diffusion De Boccard, Paris Stavropoulou-Gatsi M (1985) Kalamogdarti 10 and Kanakari (in Greek), Archaeological Deltion, 40, pp.115-117 and plate 40

Stein R, Barka A, Dieterich J (1997) Progressive failure on the North Anatolian Fault since 1939 by earthquake stress triggering. Geophys J Int 128:594-604

Stiros S (1995) Archaeological evidence of antiseismic constructions in antiquity. Ann Geophys 38:725-736

Stiros S (1998) Archaeological evidence for unusually rapid Holocene uplift rates in an active normal faulting terrain: Roman harbour of Aigeira, Gulf of Corinth, Greece. Geoarchaeology 13:731-741

Stiros S, Moschas F, Feng L, Newman A (2013) Long-term versus short-term deformation of the meizoseismal area of the 2008 Achaia-Elia $\left(M_{w} 6.4\right)$ earthquake in NW Peloponnese, Greece: Evidence from historical triangulation and morphotectonic data. Tectonophysics 592:150-158 s, Papageorgiou S (2001) Seismicity of Western Crete and the Seismol 5:381-397

Stiros SC (1996) Identification of earthquakes from archaeological data: methodology, criteria and limitations. In: Stiros S, Jones RE (eds.) Archaeoseismology, British School at Athens, Fitch Laboratory Occasional Paper 7, pp.129-152

Stiros SC (2001) The A.D. 365 Crete earthquake and possible seismic clustering during the fourth to sixth centuries $A D$ in the Eastern Mediterranean: a review of historical and archaeological data. J Struct Geol 23:545-562

Stiros SC (2010) The 8.5+ magnitude, AD365 earthquake in Crete: coastal uplift, topography changes, archaeological and historical signature. Quatern Int 216:54-63$$
\text { was created using Timble Business Centre with data obtained fro }
$$ 
National Observatory of Athens earthquake catalogue and directly exported to Google Earth).

Fig. 2 Evidence of a seismic collapse at Patras. Modified after StavropoulouGatsi (1985). 1: excavated paved road (phase A), 2: columns of phase B, toppled down; a curved arrow indicates sense of movements, 3: stylobate (base of columns) of phase $B$, built along the north sidewalk of the road of Phase A, 4: south sidewalk of the initial road, 5: foundations of a later building (phase C)

Fig. 3 (a) A typical Roman Odeon, a relatively small to very small theatre usually made of brick, concrete and hewn rocks (after http://www.vroma.org/ plautus/theatmod.jpg).

(b) Side view of the Patras Odeon, after its reconstruction in the 1960's. Contrast in building material indicates surviving ruins and reconstruction material. The scale of damage (derived from missing parts and the reconstruction) and the abandonment of the ruins of this building at the end of the $3^{\text {rd }}$ century testify to forces beyond those of invading tribes and can conspicuously be assigned to seismic forces. 


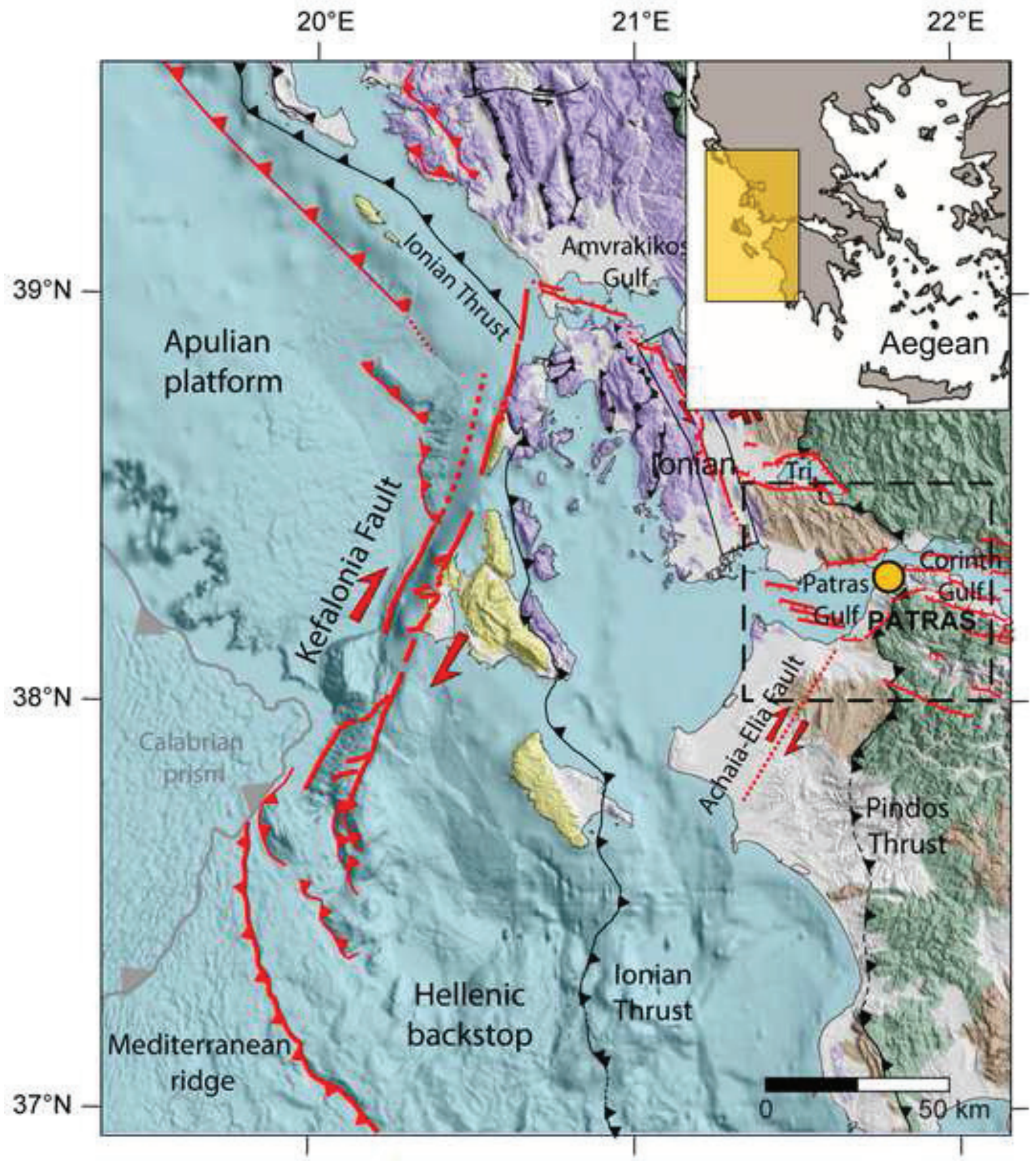




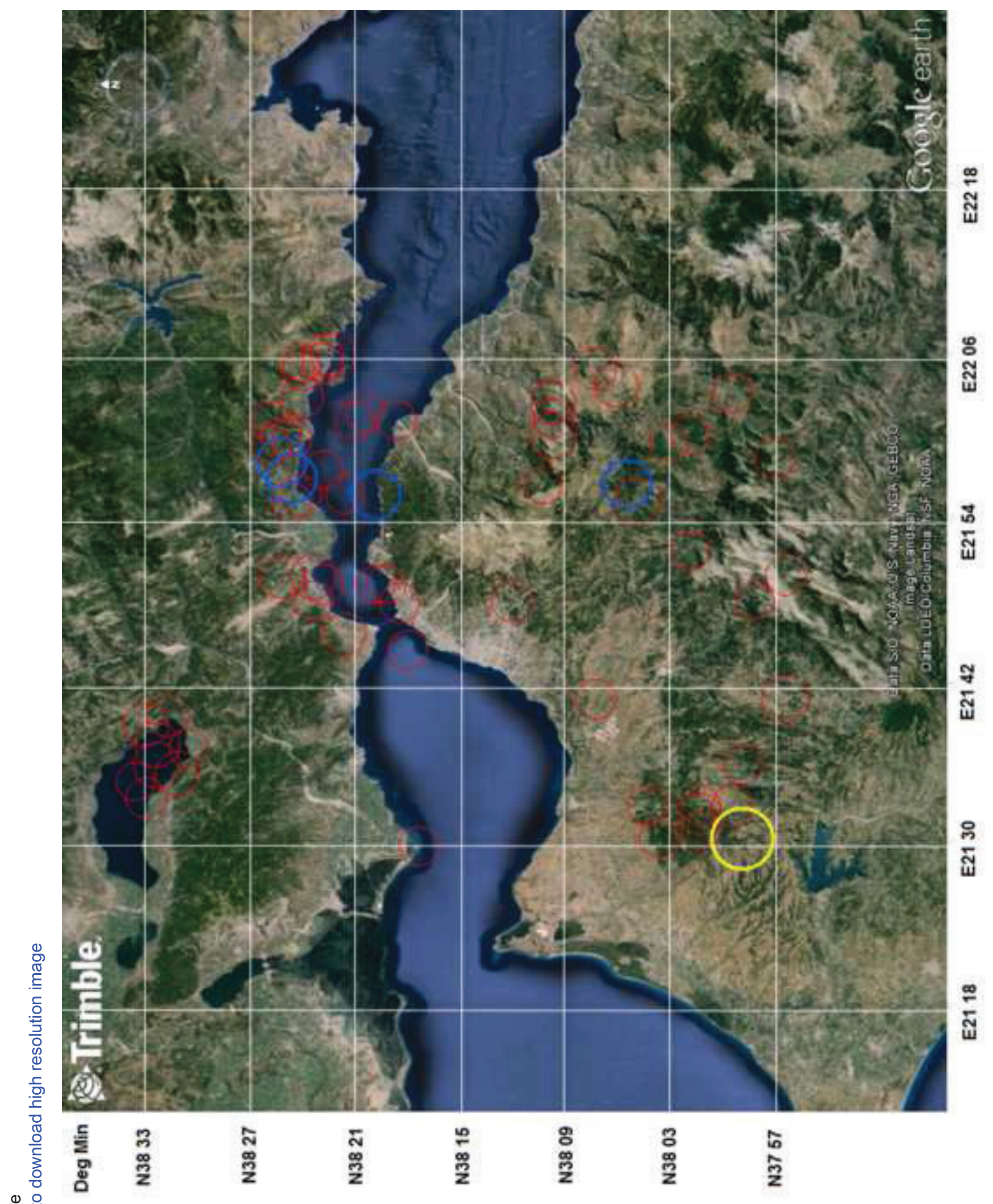




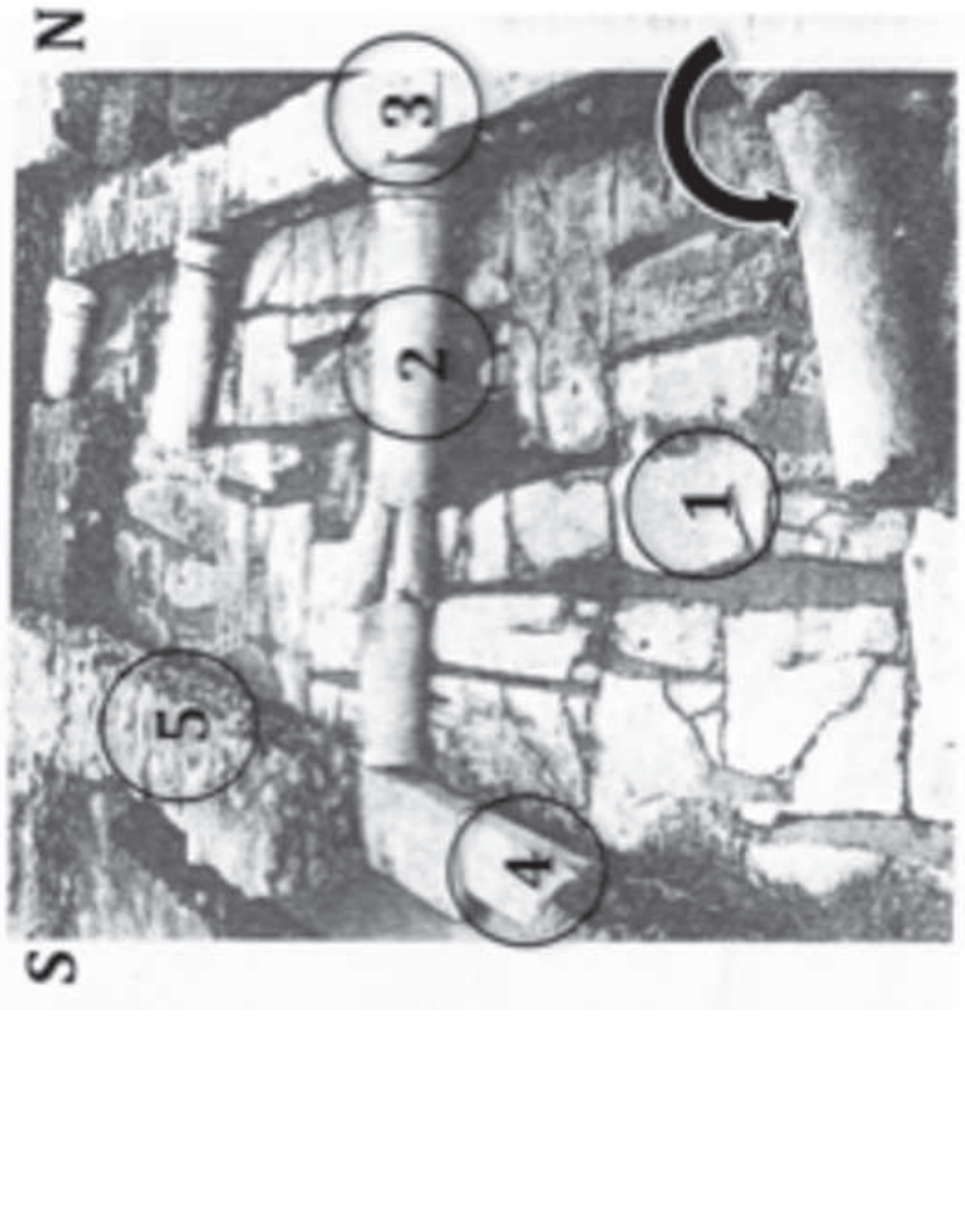




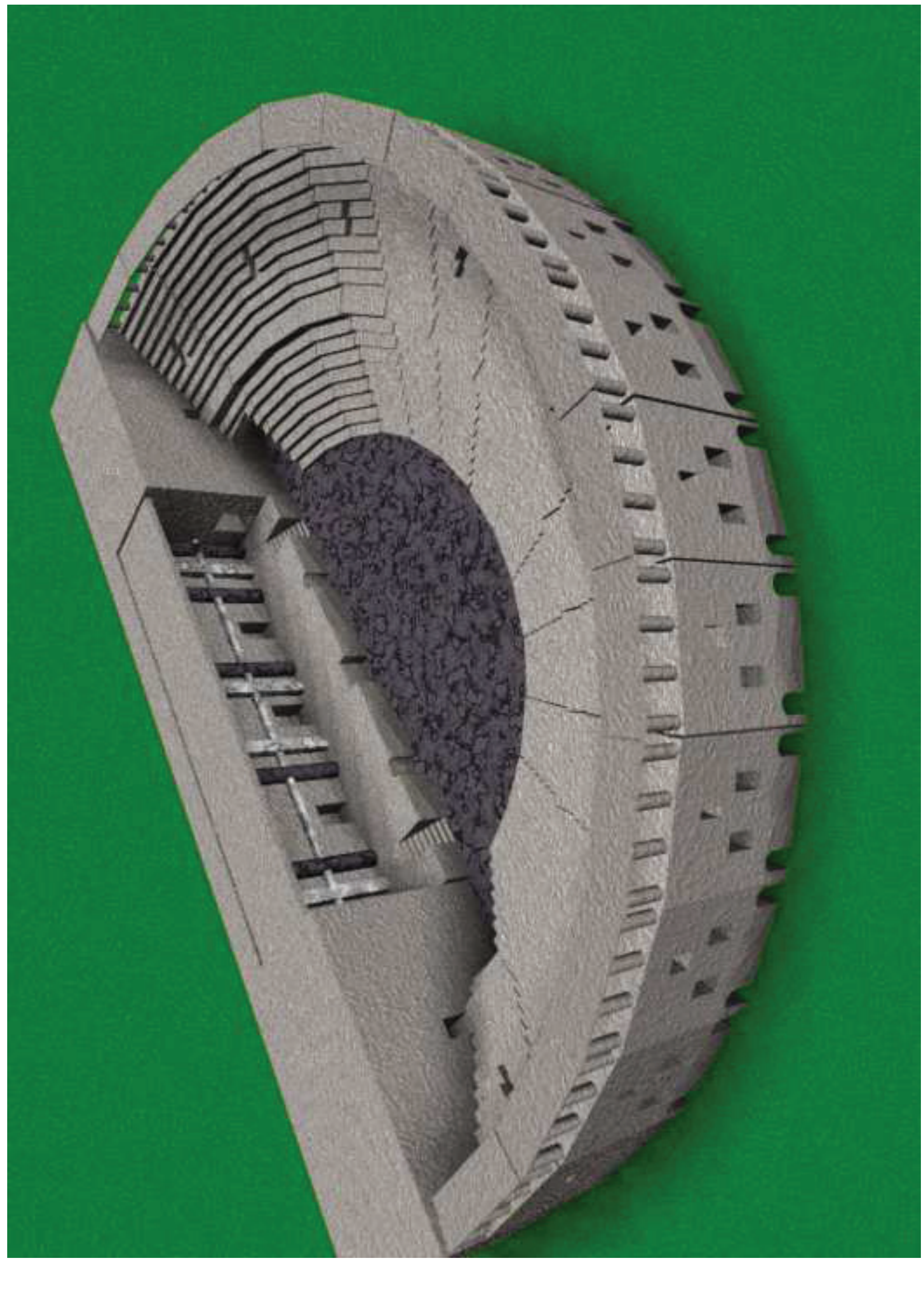




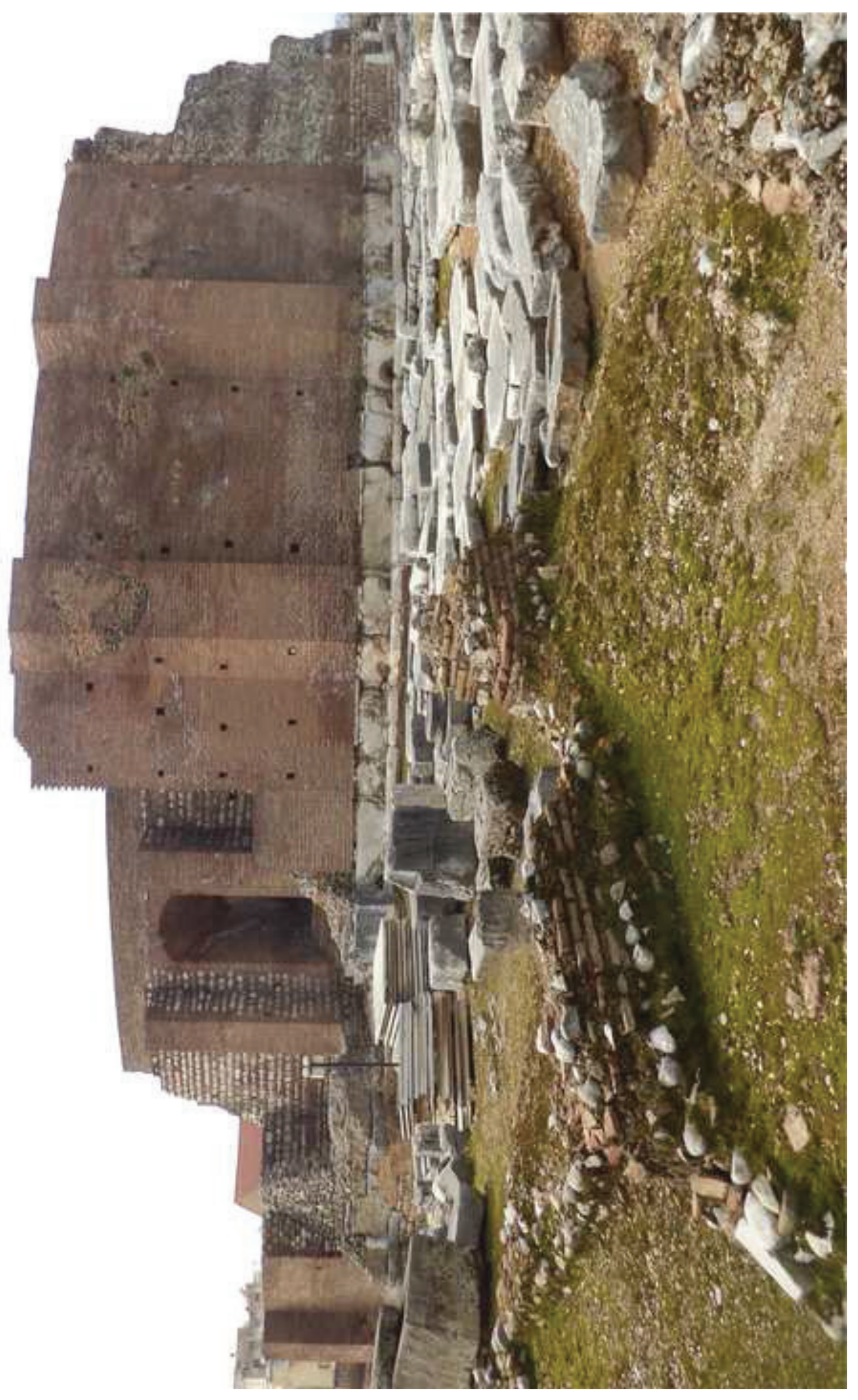

